\title{
Anmeldelse
}

Søren Schou

\section{Den ny kritik - og det moderne}

\section{Johan Fjord Jensen: Det tredje. Den postmoderne udfordring. $201 \mathrm{~s}$. Amadeus Debatbøger. Amadeus 1987.}

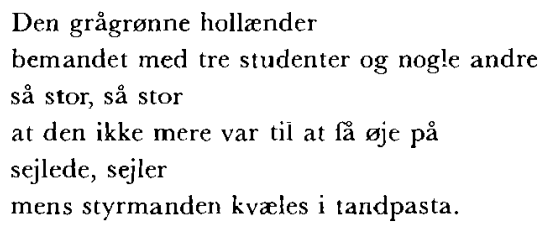

I sit efterspil (ja, »Post-ludium «!) til Otto Gelsteds "Reklameskibet« fortæller Klaus Rifbjerg, hvad der blev af den almindelige blonde student, der prøvede at sprænge skibet i luften. Eksplosionen udeblev. I stedet blev studenten forhyret på skibet, der samtidig blev så stort, at det ikke var til at danne sig en forestilling om.

Johan Fjord Jensens bog dokumenterer denne visions virkeliggørelse godt 25 år efter. Samfundsskibet, de tidligere, klare angrebsmål, har ikke alene ansat den forhenværende oppositionelle, det har tilmed vokset sig ubegribeligt stort. Helt globalt er det blevet, styrmanden har gjort sig usynlig, men magten øges i et dialektisk spil mellem decentrering og koncentration. Et dataspind uden synlig edderkop.

Den forhyrede oppositionelle inspireres ikke længere af den bestemte negation. Han foretager måske lokale indsigelser, som er ude af proportion med de globale udfordringer i situationen. Eller også samler han sine kritiske energier i et opgør med »de store fortallingers« frigørelsesforestillinger, der måske engang motiverede ham selv. Utopitænkning fører til Gulag, messer han monotont. Uden at kunne overskue eller bekymre sig om, hvilken tilintetgørelseskurs hans egen grågrønne hollænder er ude på.

Det tredje kalder Fjord sin bog - med en henvisning til den naturens tredjeinstans, de klippeskær, skibet kan forlise på. Den er lige fremra- 
gende $i$ sin redegørelse for den postindustrielle tilstand og i sit opgør med dén postmoderne tænkning, som ikke søger at vende kursen, men vænne mennesker til den.

Bogen fortjener en global behandling på sit eget niveau. Af pladsgrunde må jeg imidlertid nøjes med noget mindre, en lokal replik fra en litteraturkritisk fagfælle.

Fjords kritik af forskellige postmoderne tankestrøm ninger retter sig også mod den litteraturvidenskabelige »dekonstruktionskritik «, og det er det eneste kapitel, jeg har alvorlige indsigelser mod.

Indsigelserne gælder ikke selve karakteristikken af dekonstruktionskritikken, men det alternativ, bogen opstiller hertil. Fjord opfatter dekonstruktionskritikken (Paul de Man, J. Hillis Miller m.fl.) som en »højt intellektualiseret og sansedyrkende tilpasningsfilosofi«. Det, den tilpasser sig, er forestillingen om, »at kulturen er uden et grundlag, som den kan definere som sit centrum, og uden et historisk subjekt, den kan handle igennem«. Ved at opgive helhedsperspektivet og hengive sig til en spillende analyse af tekstens uforenelige modsigelser, stiller dekonstruktionskritikken sig uden for det moderne projekt og lagger sig på linje med anden postmoderne - aftotaliserende og centrumløs - tænkning i disse år.

Det, som dekonstruktionskritikken historisk gør op med, er nykritikken. Dén søgte et centrum, ja var »besat af syntesen«. Samtidig var det imidlertid nykritikkens vigtigste erkendelse, hævder Fjord, at syntesen selv var besat. For nykritikken indordnede ikke problemløst digtningens dele under dens helhed: »Helheden kan ikke tænkes uden igennem dens modsætninger. Og modsætningerne kan ikke begribes som sådan uden igennem den helhed, hvori de definerer sig $\mathrm{i}$ forhold til hinanden.«

At begribe dette spændte forhold mellem helhed og del var nykritikkens store erkendelse, en erkendelse som formuleredes skarpest inden for den nykritiske gruppering, Fjord kalder den modsetningshermeneutiske (til forskel fra den identitetshermeneutiske, der mere spændingsforladt så helheden gentaget i delene). Det er denne identitetsproblematiserende, men helhedssøgende variant af nykritikken, Fjord solidariserer sig med, for den er en ægte Modernitetens hermeneutik, der har den »dobbelte lidenskab«, at den på én gang vil nå til en forståelse af tekstens modsigelsesfuldhed $o g$ dens helhed.

Fjords karakteristik af begge skoler er præcis, for nykritikkens vedkommende endog usædvanlig præcis, eftersom skellet mellem en identitetsorienteret hermeneutik à la Finn Brandt-Pedersen og en modsætningsorienteret à la Cleanth Brooks ofte overses. Det problem, analysen rejser, har ikke noget med den interne karakteristik af 
de respektive skoler at gøre, men derimod med hypostaseringen af den ene - den nykritiske - som selve det moderne projekt. Her har Fjord ladet sig irritere så meget af de Mans tale om nykritikernes påståede »blindhed «, at han polemisk tilkender nykritikerne al indsigten. Når de Man via dekonstruktionen vil gøre nykritikken seende, replicerer Fjord: »Hverken modsætningerne eller enheden udgør en »blindness«, som igennem dekonstruktionen forvandles til »insight«. De udgør en indsigt, som ikke ophæver modsætningerne og ikke undertrykker dem, men heller ikke udsletter deres ubrydelige enhed - den indsigt som udgør Modernitetens erfaring, styrke og dilemma.«

Der er en påfaldende overensstemmelse mellem disse formuleringer af nykritikkens kvaliteter - og den karakteristik, Fjord helt andre steder i bogen giver af den demokratiske konsensus-opfattelse. Om politisk konsensus siger han f.eks.: »I den bringes de forskellige fortolkninger og interesser $\mathrm{i}$ forhold til hinanden på en sådan måde, at de kan danne grundlag for magtudøvelsen, samtidig med at uenigheden får lov at bestå.«

Overensstemmelsen i formuleringen af poetik- og politikidealet kan næppe være andet end tilsigtet. Med den samme dialektiske tankefigur bearbejdes forholdet mellem »enhed « og »særlighed « i poesi og politisk liv; begge steder tematiseres en enhed uden terrorisme og eksklusion af det afvigende. Tillader man sig at blande metaforerne en anelse - kun en anelse - mere, end Fjord selv gør det, fremstår et besnærende billede af digtet som et spændings- og modsætningsfyldt parlament, der har interessesammenføjningen som sin modus operandi, men alligevel ikke udgrænser, endsige forfølger, særinteresserne.

I denne opfattelse af digtningen som (anfægtet) syntesedannelse ligger et vigtigt korrektiv til dekonstruktionskritikken, et tiltrængt opgør med de Mans principielle mistænkeliggørelse af alt, hvad der tilsyneladende er »monadiske totaliteter « i digtningen. Der foregår syntesedannelser i digtningen, siger Fjord, sammenføjninger af det inkompatible - og det er et synspunkt, jeg ikke alene deler ved denne lejlighed, men også andetsteds (i Kritik 82) har argumenteret for i polemik med dekonstruktionskritikken.

Det skete med andre argumenter end Fjords, rigtignok, hentet andre steder end i nykritikken, som stadig ikke forekommer mig at være noget velegnet sted at fore angrebet fra. Vel er der helheder, som ikke er spor "metafysiske", i digtningen, men helhederne kan have tvangskarakter. Det er problematisk at hævde, som Fjord og nykritikken gør det, at dissonerende stemmer ikke udgrænses, ikke forfølges af tekstens herskende »fornuft«. Der foregăr tværtimod 
mange slags forfølgelser af det dissonerende i litteraturen, som snarere underkastes junglelovens end den parlamentariske lovs principper.

Den litteraturforskning, der orienterer sig mod den historiske materialisme og/eller psykoanalysen, påpeger, at tekstens herskende fornuft tager de mest ublu midler i brug for at bringe dissonerende stemmer til tavshed. Især psykoanalytisk inspireret kritik har udviklet et forfinet gehør for disse overdøvelsesmekanismer. Den beskæftiger sig med, hvorledes pinagtige betydningselementer fortættes til uigenkendeligheder; eller med, hvorledes forskydninger lader det pinagtige, som trods alt bliver sagt, ændres til stueren tale; eller med, hvorledes anarkistiske impulser indføjes $\mathrm{i}$ en overgribende fiktions neutraliserende strøm. Altsammen er det overdøvelsesmekanismer i teksten, der har til funktion at benægte eksistensen af disse stemmer.

Disse indvendinger ville Fjord formodentlig besvare ved at henvise til, at det er den inklusive digtning, han og nykritikken refererer til, den digtning, der lader særhederne fremtræde i ucensureret spændvidde og modsigelsesfylde - og at indvendingerne derfor kun rammer digtning på et lavere artikulationsniveau. Hvortil man for det første kunne svare, at en normativ æstetik ikke bør udstrafferes som en generel teori om digteriske teksters virkemåde. Og for det andet stille et retorisk, men alvorligt ment spørgsmål: Hvor findes den digtning, der er inklusiv i så radikal forstand, at dens »fornuft« ikke har det fornuftsstridige som problem? Og som kun taler for at differentiere, aldrig for at overdøve? Måske findes den i automatskriften, der nok lader de 100 sprogblomster blomstre, men til gengæld savner »nhed «.

Dekonstruktionskritikkens angreb på fornuften og på det moderne projekt imødegås efter min mening ikke ved en tilbagevenden til nykritikken - dette ganske uanset om dekonstruktionskritikerne har fundet det passende at profilere sig i forhold til nykritikken. Lyves denne »blind«, er den rimeligste modposition ikke at erklære den »seende

Den litteraturvidenskab, der mest vitalt forbinder sig med det moderne projekt, er ikke nykritikken, men den, der er opstået i feltet mellem historisk materialisme og psykoanalyse. Den er fraværende i Fjords rapport fra slagmarken, hvad der kan undre, ikke blot fordi Fjord har en fortid som socialhistorisk orienteret forsker, der er nyere end hans nykritiske, men også fordi hans opgør med en centrumløs, postmoderne tænkning råber på en subjektopfattelse, som nykritikken ikke kan levere, men som han kunne finde i de næunte traditioner.

Hvorfor søger Fjord så langt tilbage i sin karriere? Måske fordi der 
er to træk ved nykritikken, som får den til at ligne alternativet til dekonstruktionskritikken og dermed et genuint moderne projekt: dens (sofistikerede) synteseopfattelse og dens autonomikonception. Der er imidlertid problemer ved dem begge.

Hvad nykritikkens synteseopfattelse angår, er det et problem, at Fjord tilslutter sig den uden at diskutere, hvilken instans der frembringer syntesen. Han citerer Paul de Man, der kritisk påpeger den mærkværdighed ved nykritikken, at den på én gang anskuer digterværket som en fra forfatterens hensigter udskilt ting og som en organisk helhed. Påpegningen af denne besynderlighed bliver, såvidt jeg kan se, ikke direkte kommenteret af Fjord, og må stå ved magt - de Mans egne forsøg på at dekonstruere nykritikkens tankebygning ufortalt.

Tilsyneladende mener Fjord ikke, at syntesen skal forstås »organisk " (hvad er alternativet forresten? Uorganisk?). Men det forbliver uklart, hvorledes den overhovedet fremkommer, for Fjord vægrer sig lige så bestemt som nykritikerne ved at diskutere forholdet mellem skabersubjekt og værk, antagelig fordi han mener, det ville føre lukt ind $\mathrm{i}$ intentionalismens uholdbarheder.

Således behøver det imidlertid ikke gå. Den psykoanalytisk prægede litteraturforskning peger på mere differentierede alternativer end værket som intentionalitetens udtryk på den ene side, og værket som en »udskilt ting« på den anden. Sagt i yderste korthed beskæftiger en sådan kritik sig både med jeg-nære helhedsdannelser i digtningen (det intentionelle aspekt), med ubevidste »vektoriseringer « (mønstre af ikke-intentionel karakter) og med den modsigelsesfuldhed, de to typer »krav på teksten« frembringer i værket.

En psykoanalytisk praget litteraturforskning, der således lokaliserer modsigelser mellem intentionelle og ubevidst manifesterede værkstrukturer, kunne synes at være mere i slægt med den forskelsfremhævende dekonstruktionskritik end med den syntesefremhævende nykritik. Men den er ikke slet og ret en variant af dekonstruktionskritikken, for den forholder sig til et betydningsdannelsernes sted, nemlig forfatterpersonen, og frigør sig således ingenlunde fra en subjektopfattelse. Blot er dette subjekt ikke et gennemlyst selvnærvær, et hus med én veloplyst bolig, men et hus i splid med sig selv, med et upstairs og et downstairs og et system i striden mellem dem.

Skal det moderne projekt fastholdes i polemik med en centrumløs postmodernisme, er en subjektopfattelse uomgængelig - en sofistikeret subjektopfattelse, vel at mærke, der ligger lige så langt fra en »metafysisk « selvnærværsfilosofi som fra en »atomiserende« attituderelativisme. Ved at udpege nykritikken som dét moderne alternativ til dekonstruktionskritikken, søger Fjord en forbundsfælle, der ikke 
ligner dem, han andetsteds i bogen allierer sig med, for nykritikken udgrænser skabersubjektet som et uvidenskabeligt anliggende.

Hermed er vi på vej over i spørgsmålet om nykritikkens autonomikonception, den anden mulige grund til, at nykritikken kunne betragtes som et genuint moderne projekt. Hvis autonomibegrebet rummer en kvalitet som "genstridighed «, kunne den vel være værd at spille ud imod en tilpasningsfilosofi som postmodernismen.

Her må man imidlertid minde om, at den autonomi, nykritikerne talte om - og som de havde god grund til at tale om dengang, da en positivistisk biografisme endnu var magtfuld - især gjaldt forholdet mellem opståelsesbetingelser og værk: Verset ryster stolt sin løvemanke og spotter forfatterens menen og villen. Uden for nykritikken findes imidlertid en autonomiopfattelse, som peger på en anden type "genstridighed « end den, der retter sig mod opståelsesbetingelserne. Mest markant repræsenteres den af Adorno, for hvem kunstværket var autonomt i forhold til den herskende fornuft, en indsigelse mod umenneskeligheden.

Det er i det hele taget påfaldende, at Adorno er totalt fraværende i bogens specifikt litteraturvidenskabelige diskussion, mens han andetsteds (med Horkheimer) er en central reference.

Måske læser jeg kapitlet skævt. Måske Fjords hensigt ikke så meget er at udnævne nykritikken til dét moderne projekt på litteraturvidenskabens område, som mere beskedent at vise, at den er mere indsigtsfuld, og intimere knyttet til det moderne projekt, end den har făet ry for. Besynderligt er det under alle omstændigheder, at nykritikken i den faktiske argumentation făr lov at monopolisere de genuint moderne indsigter, og at den især fremhæues for sin opfattelse af de digteriske modsigelser, der for mig at se er uforenelig med andre moderne retninger (psyko-kritik, Adorno, etc.). Så mon ikke jeg har læst rigtigt alligevel?

Nykritikken forekommer i bekræftende fald at have større affektionsværdi for Fjord end brugsvardi i konfrontationen med den postmoderne udfordring - uanset at den i Cleanth Brooks havde en bedre tekstlæser og i I. A. Richards en bedre receptionsanalytiker end nogen, der kan opdrives i den dekonstruktivistiske lejr.

De teoretiske alternativer må opsøges andre steder, og de er i øvrigt ingenlunde sammensvejsede til ét moderne, litteraturvidenskabeligt projekt. Allerede de få referencer, jeg her har givet, er rigeligt heterogene; der er en betydelig afstand mellem den psyko-kritik, som ser de oprørske tendenser som noget, der så at sige knægtes af tekstens eget politi - og Adornos opfattelse af kunstværket som indsigelse mod umenneskeligheden. 
Opgaven er vel ikke at overvinde disse forskelligheder mellem skolerne, men at udvikle dem på det konsensus-grundlag, der udgøres af solidariteten med det moderne projekt. At udvikle sig vil bl.a. sige at bringe sig på niveau med dekonstruktionskritikken i samtidssensibilitet, at lade sig påvirke af dens tæft for sprogspillenes subtiliteter, men også at imødegå dens spaltning mellem xstetik og handlingsverden ved at analysere og kritisere - med Fjords formulering - »de simulationer, hvormed magten i meningstabets samfund legitimerer sit herredømme«.

Kritisk holdning uden samtidssensibilitet er nogenlunde lige så ufarligt som samtidssensibilitet uden kritik. Mangler det ene element, vil det gå litteraturforskerne, som det gik de fhv. oppositionelle $\mathrm{i}$ Rifbjergs »Postludium«:

Med et nyklippet omstigningskort.

forsvinder de tre gentlemen $\mathrm{i}$ morgendisen. 
Elektronisk version af artikel i KK 60. Forlaget Medusa 1988. 